\title{
Influence of steroids and GnRH on biosynthesis and secretion of secretogranin II and chromogranin A in relation to $\mathrm{LH}$ release in L $\beta T 2$ gonadotroph cells
}

\author{
L Nicol, J R McNeilly, M Stridsberg ${ }^{1}$, J L Crawford \\ and A S McNeilly \\ MRC Human Reproductive Sciences Unit, Centre for Reproductive Biology, 37 Chalmers Street, Edinburgh EH3 9ET, UK \\ ${ }^{1}$ Department of Medical Sciences, Clinical Chemistry, University Hospital, S-751 85 Uppsala, Sweden \\ (Requests for offprints should be addressed to L Nicol; Email: I.nicol@hrsu.mrc.ac.uk) \\ (J L Crawford is now at Reproductive Biology Group, AgResearch, Wallaceville Animal Research Centre, PO Box 40063, Upper Hutt, New Zealand)
}

\begin{abstract}
The granin proteins secretogranin II (SgII) and chromogranin A ( $\mathrm{CgA})$ are commonly found associated with $\mathrm{LH}$ and/or FSH within specialised secretory granules in gonadotroph cells, and it is possible that they play an important role in the differential secretion of the gonadotrophins. In this study we have examined the regulation of the biosynthesis and secretion of SgII and $\mathrm{CgA}$, in relation to $\mathrm{LH}$ secretion, in the $\mathrm{L} \beta \mathrm{T} 2$ mouse pituitary gonadotroph cell line.

Three experiments were carried out to investigate the effects of oestradiol (E2) and dexamethasone (Dex) in the presence and absence of GnRH (experiment 1), differing $\mathrm{GnRH}$ concentrations (experiment 2) and alterations in GnRH pulse frequency (experiment 3). In experiment 1, exposure to E2, Dex or E2+Dex, either with or without $\mathrm{GnRH}$ treatment, resulted in increased $\mathrm{LH}$ secretion. Steroids alone had no effect on LH $\beta$ mRNA levels, but in the presence of GnRH LH $\beta$ mRNA levels were increased in Dex- and E2+Dex-treated cells. GnRH receptor (GnRH-R) mRNA levels were up-regulated by Dex and E2+Dex, but were unaffected by GnRH. There were no steroid-induced changes in SgII or CgA mRNA, but increased levels of CgA mRNA were observed after $\mathrm{GnRH}$ treatment in cells cultured in the presence of Dex. In experiment 2, increasing concentrations of $\mathrm{GnRH}$ resulted in increases in $\mathrm{LH}$ secretion that were inversely dose-dependent. No changes in LH $\beta$, GnRH-R or SgII mRNA levels were observed, but there were dosedependent increases in CgA mRNA levels. In experiment 3 , GnRH was given as either 1 pulse/day or 4 pulses/day
\end{abstract}

for 3 days. Both pulse regimes resulted in increased $\mathrm{LH}$, $\mathrm{SgII}$ and $\mathrm{CgA}$ secretion compared with controls during the first $15 \mathrm{~min}$ pulse on day 3. Exposure to $\mathrm{GnRH}$ at 4 pulses/day increased LH and SgII secretion compared with controls during all 4 pulses, but secretion of both proteins was reduced during pulses 2-4 compared with pulse 1 . $\mathrm{CgA}$ secretion also increased due to $\mathrm{GnRH}$ in pulse 1, but was decreased by $\mathrm{GnRH}$ treatment during pulse 2, and unchanged by GnRH during pulses 3 and 4. Total daily secretion of LH and SgII from cells given 1 pulse/day of $\mathrm{GnRH}$ increased compared with controls on all three treatment days, while total $\mathrm{CgA}$ secretion increased in response to GnRH on days 2 and 3 only. Intracellular levels of SgII, but not $\mathrm{LH}$, decreased after GnRH treatment. In contrast, intracellular CgA was increased, but only after 4 pulses/day of GnRH. Levels of LH $\beta$, but not SgII, mRNA were increased by both pulse regimes, while CgA mRNA levels increased after 1 pulse/day of GnRH.

These results indicate that there is a close correlation between the GnRH-stimulated release of $\mathrm{LH}$ and SgII from L $\beta$ T2 cells, suggesting that SgII may have an influential role in the regulated secretion of $\mathrm{LH}$, possibly by inducing $\mathrm{LH}$ aggregation to facilitate trafficking into secretory granules. CgA secretion does not appear to be closely associated with that of $\mathrm{LH}$, but $\mathrm{CgA}$ expression does appear to be regulated by $\mathrm{GnRH}$, which may indicate involvement in the control of $\mathrm{LH}$ secretion, possibly by influencing the proportion of $\mathrm{LH}$ in the different types of secretory granules.

Journal of Endocrinology (2002) 174, 473-483

\section{Introduction}

Normal reproductive function is dependent on the production of the gonadotrophins, luteinising hormone ( $\mathrm{LH}$ ) and follicle-stimulating hormone (FSH), from specialised gonadotroph cells in the anterior pituitary. Synthesis and secretion of the gonadotrophins are regulated by pulsatile release of gonadotrophin-releasing hormone $(\mathrm{GnRH})$ from the hypothalamus (Clarke \& Cummins 1982), by the negative feedback effects of gonadal steroids, acting 
either directly at the pituitary or indirectly by regulating GnRH release from the hypothalamus (Gharib et al. 1990, McNeilly et al. 1991, Padmanabhan \& McNeilly 2001), and by the gonadal peptides inhibin, activin and follistatin (Vale et al. 1988). Gonadotrophs are reported to be bihormonal (Liu et al. 1988, Currie \& McNeilly 1995, Thomas \& Clarke 1997), but under certain physiological and experimental conditions, monohormonal cells have been identified (Childs et al. 1994, Taragnat et al. 1998). Despite the bihormonal nature of gonadotrophs, these cells are capable of differentially regulating the secretion of $\mathrm{LH}$ and FSH. LH is stored intracellularly and released mainly in response to pulses of $\mathrm{GnRH}$ via a regulated secretory pathway (Burgess \& Kelly 1987), although minimal release can occur constitutively (McNeilly et al. 1991). FSH is largely secreted via a 'constitutive-like' pathway, although there is evidence that this hormone may also be released by an alternative 'regulated' pathway (Farnworth 1995). At the sub-cellular level specialised secretory granules, containing either one or both gonadotrophins, have been observed (Childs et al. 1987, Lloyd \& Childs 1988, Watanabe et al. 1991, Tougard \& Tixier-Vidal 1994, Farnworth 1995), and the differential secretion of LH and FSH has been attributed to changes in the total number of granules and/or in the proportion of each type of granule within a cell (Childs et al. 1987, Watanabe et al. 1991). Secretory granules within neuroendocrine cells typically also contain acidic soluble proteins from the granin family (Huttner et al. 1991, Ozawa \& Takata 1995). These proteins aggregate at low $\mathrm{pH}$ and high calcium concentrations, conditions found in the trans-Golgi network (TGN), and it has been suggested that they function as 'aggregation-inducers', involved in the packaging of peptide hormones and neuropeptides into secretory granules formed within the TGN (Chanat \& Huttner 1991, Watanabe et al. 1991). The three major granin proteins, secretogranin II (SgII), chromogranin A (CgA) and chromogranin $\mathrm{B}(\mathrm{CgB})$, have all been detected within gonadotrophs in the rat anterior pituitary (Rundle et al. 1986, Watanabe et al. 1991). Immunocytochemical studies revealed an association between SgII and LH in small, electron-dense granules and between $\mathrm{CgA}, \mathrm{FSH}$, and to a lesser extent $\mathrm{LH}$, in larger, moderately electron-dense granules. It has been suggested that these subsets of secretory granules involve different sorting mechanisms, which may reflect two regulated pathways of secretion in gonadotrophs (Watanabe et al. 1991, 1993). In GnRHstimulated pituitary cell aggregates SgII has been shown to be co-released with LH (Sion et al. 1988), reflecting the close proximity of these proteins within secretory granules. A third, intermediate type of secretory granule, which is normally observed only sporadically, appears more abundant after acute $\mathrm{GnRH}$ treatment of gonadotrophs. These are immunopositive for both gonadotrophins and both granins, but SgII and $\mathrm{LH}$ are localised together in an electron-dense core and $\mathrm{CgA}$ and FSH are observed in the electron-lucent area peripheral to this (Watanabe et al. 1993, Crawford et al. 2002b). It is postulated that hyperstimulation of the gonadotrophs results in a dramatic increase in the flow of secretory proteins through the TGN, and that the processes involved in partitioning different secretory proteins/granins fail, increasing the number of intermediate granules (Watanabe et al. 1993). It is still unclear how the formation of these granules relates to the increased secretion of the gonadotrophins in response to $\mathrm{GnRH}$. It is interesting to note that the synthesis and secretion of SgII and $\mathrm{CgA}$ within the pituitary appear to be regulated by gonadal steroids and by glucocorticoids. Oestradiol (E2) down-regulated both SgII and CgA mRNA in female rat pituitaries (Anouar \& Duval 1992). SgII release, along with that of LH, was suppressed after E2 treatment, leading to an increase in pituitary content for these two proteins. CgA cell content, on the other hand, was reduced by E2 treatment (Anouar \& Duval 1991), which could be attributed to either increased secretion and/or increased degradation of CgA. In contrast, $\mathrm{CgA}$ is reported to be up-regulated by dexamethasone (Dex) (Fischer-Colbrie et al. 1989). Sequence analysis of the bovine CgA promoter revealed the presence of sequences similar to the consensus glucocorticoid and oestrogen response elements (Iacangelo et al. 1991).

The L $\beta$ T2 mouse gonadotroph cell line has previously been shown to exhibit structural and functional characteristics of normal pituitary gonadotrophs (Turgeon et al. 1996) and, as shown in the present study, these cells also express the granins. We have utilised this cell line to investigate the effects of E2, Dex and GnRH on the expression, storage and secretion of the granin proteins $\mathrm{SgII}$ and $\mathrm{CgA}$ in relation to the regulated secretion of $\mathrm{LH}$.

\section{Materials and Methods}

This study was divided into three experiments whereby the effects of E2 and/or Dex in the presence and absence of GnRH (experiment 1), differing GnRH concentrations (experiment 2) and alterations in $\mathrm{GnRH}$ pulse frequency (experiment 3) were investigated. LH secretion and mRNA levels for LH $\beta$, GnRH receptor (GnRH-R), SgII and $\mathrm{CgA}$ were measured in experiments 1 and 2. LH, SgII and $\mathrm{CgA}$ secretion and intracellular content, as well as LH $\beta$, GnRH-R, SgII and CgA mRNA levels were investigated in experiment 3 .

\section{Cell culture}

L $\beta$ T2 cells were kindly provided by Dr P Mellon (University of California, San Diego, CA, USA). They were grown in DMEM, 10\% foetal calf serum (FCS), $50 \mathrm{U} / \mathrm{ml}$ penicillin and $50 \mu \mathrm{g} / \mathrm{ml}$ streptomycin at $37^{\circ} \mathrm{C}$ in $5 \% \mathrm{CO}_{2}$, on flasks coated with Matrigel (Becton 
Dickinson Labware, Oxford, Oxon, UK) diluted 1:29 in PBS. For experimental evaluation cells were plated, at a density of $3.5 \times 10^{6}$ cells/well, on six-well plates coated with Matrigel (diluted 1:3), in phenol red-free DMEM $(1 \mathrm{~g} / 1$ glucose) supplemented with $10 \%$ charcoal-treated FCS, $3.5 \mathrm{~g} / 1$ glucose, $4 \mathrm{mM}$ L-glutamine, $50 \mathrm{U} / \mathrm{ml}$ penicillin and $50 \mu \mathrm{g} / \mathrm{ml}$ streptomycin. They were allowed to attach for approximately $3 \mathrm{~h}$, then basal medium was replaced as required for each experiment. Cell culture reagents were obtained from Sigma (Poole, Dorset, UK) unless otherwise indicated.

To assess the effects of E2, Dex and GnRH (experiment $1)$, cells were grown in medium that was either steroidfree, or supplemented with $0 \cdot 2 \mathrm{nM}$ E2, $20 \mathrm{nM}$ Dex or $0 \cdot 2 \mathrm{nM} \mathrm{E} 2+20 \mathrm{nM}$ Dex. After overnight culture, medium was removed and replaced with fresh medium for $30 \mathrm{~min}$ to establish a baseline for secretion. This was then replaced with medium containing $10 \mathrm{nM}$ GnRH (Peninsula Laboratories Europe Ltd, St Helens, Merseyside, UK) for $15 \mathrm{~min}$, followed by $\mathrm{GnRH}$-free medium for an inter-pulse interval of $75 \mathrm{~min}$. Cells were given 4 pulses of GnRH per day over 3 days. Control cells had their medium changed daily. To investigate the effects of different GnRH concentrations (experiment 2), all cells were cultured in medium supplemented with E2+Dex, and GnRH was administered as 4 pulses/day for 3 days as described above, using concentrations of $0,10,50$ and $200 \mathrm{nM}$. To determine the effects of different $\mathrm{GnRH}$ pulse frequencies (experiment 3), cells were again cultured in E2+Dex, and 0 or $10 \mathrm{nM} \mathrm{GnRH}$ was given as either one $15 \mathrm{~min}$ pulse/day or four $15 \mathrm{~min}$ pulses/day over 3 days as described above.

Media samples were collected at each medium change and stored at $-20{ }^{\circ} \mathrm{C}$ for RIA. For all experiments, on day 4 cells were suspended in RNazolB (AMS Biotechnology (Europe) Ltd, Abingdon, Oxon, UK) and total RNA prepared, according to the manufacturer's protocol, for Northern analysis or quantitative RT-PCR. In experiment 3 some samples were suspended in $100 \mathrm{mM}$ sodium carbonate $\mathrm{pH} 8.4$ containing Complete Protease Inhibitors (Roche), incubated at room temperature for $1 \mathrm{~h}$, and then subjected to three cycles of rapid freeze-thawing to release intracellular proteins. After centrifugation at $12000 \mathrm{~g}$ for 5 min supernatants were stored at $-20^{\circ} \mathrm{C}$ for RIA.

\section{RIA}

LH assay The concentration of LH in cell culture media and intracellular protein extracts was measured by RIA using reagents supplied by Dr A Parlow (NIDDK, Torrance, CA, USA), with all samples from each experiment being assayed in duplicate in the same assay as previously described (McNeilly et al. 1996). The reference preparation used was rLH-RP-1 and the minimum detectable concentration was $200 \mathrm{pg} / \mathrm{ml}$. The intra- and inter-assay coefficients of variation were $<10 \%$.
Granins SgII was measured as secretoneurin. A peptide covering the human SgII amino acid sequence 154-165 (hSgII154-165), with an additional cysteine residue in the C-terminal, was synthesised using Fmoc techniques. Before injection into rabbits, the peptide was coupled to Imject maleimide-activated keyhole limpet cyanogen according to the manufacturer's instructions (Pierce, Rockford, IL, USA). For preparation of tracer, the peptide was labelled with ${ }^{125}$ I (Amersham Pharmacia Biotech UK Ltd, Little Chalfont, Bucks, UK) using the chloramine-T method as described previously (Stridsberg et al. 1995). The assay was constructed as follows: standards and unknown samples were incubated with tracer (30000 c.p.m./tube) and primary antibody $(1 / 105000)$ for 3 days at $4{ }^{\circ} \mathrm{C}$. All standards and samples were assayed in duplicate. Antibody-bound radioactivity was separated from free tracer by addition of a secondary antibody, goat anti-rabbit IgG, coupled to a solid phase (Decanting suspension 3; Pharmacia Biotech, Uppsala, Sweden). The antibody-bound radioactivity was measured in a gamma counter (Auto gamma; Wallac, Pharmacia Biotech) and the data were calculated using a logit-log transformation program (Multicalc; Wallac). CgA was measured using an antibody to either human CgA amino acid sequence 324-337 (hCgA324-337), which detects the WE-14 region of CgA (Portela-Gomes \& Stridsberg 2001), or to human CgA amino acid sequence 17-38 (hCgA17-38), which detects vasostatin (Stridsberg et al. 2000, PortelaGomes \& Stridsberg 2001). For hCgA324-337 the assay method was performed as described above with a primary antibody dilution of 1/90 000. The hCgA17-38 assay was also performed as described above, with a primary antibody dilution of 1/120 000 (Stridsberg et al. 2000). All granin assays showed sufficient interspecies cross-reaction (Stridsberg et al. 2000) to allow measurement in samples from the mouse-derived L $\beta \mathrm{T} 2$ cell line. The detection limits were $<10 \mathrm{fmol}$ and the total assay variation was $<10 \%$ for all assays.

\section{Northern blots}

The mouse GnRH-R (1.2 kb) cDNA (Tsutsumi et al. 1992) was obtained in house from Mr R Sellar (MRC Human Reproductive Sciences Unit, Edinburgh, UK), the bovine SgII $(2.3 \mathrm{~kb})$ cDNA from Dr R FischerColbrie (University of Innsbruck, Innsbruck, Austria) and the human CgA $(1.8 \mathrm{~kb})$ cDNA from ATCC (Manassas, VA, USA). The rat $18 \mathrm{~S}$ rRNA cDNA was from Dr K Turner (MRC Human Reproductive Sciences Unit). Radiolabelled cDNA probes were prepared to high specific activity $\left(>1 \times 10^{9}\right.$ c.p.m. $\left./ \mu \mathrm{g}\right)$ with $\left[\alpha_{-}{ }^{32} \mathrm{P}\right] \mathrm{dCTP}$ using a Rediprime kit (Amersham Pharmacia Biotech).

Samples of total RNA $(20 \mu \mathrm{g})$ were separated on $1.5 \%$ agarose $/ 0.66 \mathrm{M}$ formaldehyde gels and transferred to Hybond N (Amersham Pharmacia Biotech). After UV cross-linking for $2 \mathrm{~min}$, membranes were pre-hybridised 
for $4 \mathrm{~h}$ at $65^{\circ} \mathrm{C}$ in buffer containing $0.2 \mathrm{M}$ sodium phosphate, $\mathrm{pH} 7 \cdot 2,1 \mathrm{mM}$ EDTA, $\mathrm{pH} 8,7 \%$ (w/v) SDS, $1 \%(\mathrm{w} / \mathrm{v})$ BSA and $15 \%(\mathrm{v} / \mathrm{v})$ deionised formamide. Hybridisation was carried out overnight at $65^{\circ} \mathrm{C}$ in fresh buffer containing radiolabelled cDNA probe at $2-3 \times 10^{6}$ c.p.m. $/ \mathrm{ml}$. Membranes were washed $3 \times 20 \mathrm{~min}$ in $40 \mathrm{mM}$ sodium phosphate, $\mathrm{pH} 7 \cdot 2,1 \mathrm{mM}$ EDTA, $\mathrm{pH} 8$ and $1 \%(\mathrm{w} / \mathrm{v})$ SDS. Intensity of bands was quantified using a Storm 860 phosphorimager (Molecular Dynamics, Chesham, Bucks, UK) and changes in mRNA levels were assessed in relation to $18 \mathrm{~S}$ rRNA levels.

\section{Quantitative RT-PCR}

Our Northern blot signals for the LH $\beta$ transcript appeared to be quite low, making detection and subsequent analysis more difficult. Consequently, we have utilised the more sensitive Taqman quantitative PCR technique to assess changes in expression of this mRNA.

LH $\beta$ primers and probe were designed using Primer Express software (PE Biosystems, Warrington, Cheshire, UK) and synthesised by PE Biosystems. Sequences were: forward primer: TGTCCTAGCATGGTCCGAG TACT; reverse primer: AGGGCTACAGGAAAGGA GACTATG; probe (FAM labelled): CGGCTGCTTT GCCTCCTGTGC. Ribosomal 18S primers and probe were from a Taqman Ribosomal RNA Control Reagents kit (VIC labelled probe; PE Biosystems).

Aliquots of total RNA were treated with DNase I using DNA-free (Ambion (Europe) Ltd, Huntingdon, Cambs, UK) according to manufacturer's protocol. Samples were then reverse transcribed, using oligo $\mathrm{d}(\mathrm{T}) 16$, with Taqman Reverse Transcription Reagents (PE Biosystems) according to the manufacturer's protocol, using a programme of $10 \mathrm{~min}$ at $25^{\circ} \mathrm{C}, 30 \mathrm{~min}$ at $48{ }^{\circ} \mathrm{C}$ and $5 \mathrm{~min}$ at $95^{\circ} \mathrm{C}$. DNase-treated RNA was added at $10 \mathrm{ng} / \mu \mathrm{l}$. For PCR a reaction mix was prepared consisting of Taqman Universal PCR Master Mix $(1 \times)$, LH $\beta$ forward and reverse primers $(300 \mathrm{nM}$ each), LH $\beta$ probe $(200 \mathrm{nM})$, ribosomal $18 \mathrm{~S}$ forward and reverse primers $(50 \mathrm{nM}$ each) and ribosomal $18 \mathrm{~S}$ probe $(200 \mathrm{nM})$. This was aliquoted into separate tubes for each sample, then cDNA was added at $1 \mu \mathrm{l} / 25 \mu \mathrm{l}$ reaction mix (equivalent to $10 \mathrm{ng}$ total $\mathrm{RNA} / 25 \mu \mathrm{l}$ ), and mixed well. Twenty-five microlitre aliquots were transferred to wells in a 96-well PCR plate, with each sample added in duplicate. Optical caps were fixed onto the plates and the PCR reaction run on an ABI Prism 7700 PCR machine (PE Biosystems) using standard conditions. Controls included cDNA prepared with omission of Multiscribe reverse transcriptase enzyme to check for efficiency of DNase treatment. Prior to analysis, a validation assay was performed to demonstrate that amplification of target gene and the reference (18S) were approximately equal. Quantification was performed by the $\Delta \Delta \mathrm{Ct}$ method (Bulletin \#5; PE Biosystems). A standard PCR reaction using the LH $\beta$ primers was run on an agarose gel to confirm amplification of a single product of the correct size.

\section{Statistical analysis}

Data are reported as means \pm S.E.M. Comparisons between controls and treatment groups were analysed by an unpaired $t$-test. Differences between multiple groups were determined by one-way ANOVA, followed by Fisher's protected least square differences test using Statview version 4.02 (Abacus Concepts Ltd, Berkeley, CA, USA). $P<0 \cdot 05$ was considered significant.

\section{Results}

\section{Experiment 1: effects of E2, Dex and GnRH}

A preliminary experiment, performed to establish the optimum culture conditions for further studies, examined the effects of $0.2 \mathrm{nM}$ E2, $20 \mathrm{nM}$ Dex and $0.2 \mathrm{nM}$ $\mathrm{E} 2+20 \mathrm{nM}$ Dex, with and without GnRH treatment, on LH secretion and LH $\beta$, GnRH-R, SgII and CgA mRNA levels. LH secretion results for each pulse of $\mathrm{GnRH}$ represent the total $\mathrm{LH}$ secreted during the $15 \mathrm{~min} \mathrm{GnRH}$ exposure and the 75 min inter-pulse interval. By the third day of culture all steroid treatments resulted in increased $(P<0 \cdot 001) \mathrm{LH}$ secretion in response to the first $\mathrm{GnRH}$ pulse (Fig. 1a). Dex and E2+Dex treatments increased $(P<0 \cdot 001)$ LH secretion compared with E2 alone. During pulses $2-4$ LH secretion was reduced $(P<0 \cdot 05)$ in cells given Dex and E2+Dex compared with control and E2-treated cells. More $(P<0 \cdot 001) \mathrm{LH}$ was released in response to pulse 1 , compared with pulses $2-4$. Total daily $\mathrm{LH}$ secretion from cells cultured in the absence of $\mathrm{GnRH}$ was also increased $(P<0 \cdot 01)$ on days 2 and 3 in response to all steroid treatments (data not shown). In the absence of GnRH, LH $\beta$ mRNA levels were unchanged by steroid treatment, but in the presence of GnRH, LH $\beta$ mRNA expression was increased by Dex and E2+Dex, compared with GnRH-treated controls $(P<0 \cdot 01)$ and with the corresponding treatment groups within non-GnRHtreated cells $(P<0 \cdot 05, P<0 \cdot 01$ respectively; Fig. 1b (i)). GnRH-R mRNA levels were increased by Dex and E2+Dex (no GnRH: $P<0 \cdot 01, P<0.001$ respectively; + GnRH: $P<0 \cdot 001)$, but GnRH had no effect on GnRH-R mRNA (Fig. 1b (ii)). There were no significant changes in SgII or CgA message levels as a result of steroid treatment. However, up-regulation $(P<0 \cdot 05)$ of $\mathrm{CgA}$ mRNA in response to GnRH was observed in Dex-treated cells (Fig. 1b (iv)).

\section{Experiment 2: effects of differing $\mathrm{GnRH}$ concentrations}

Having established that LH secretion, and LH $\beta$ and GnRH-R mRNA levels, were optimally increased in 
(a)

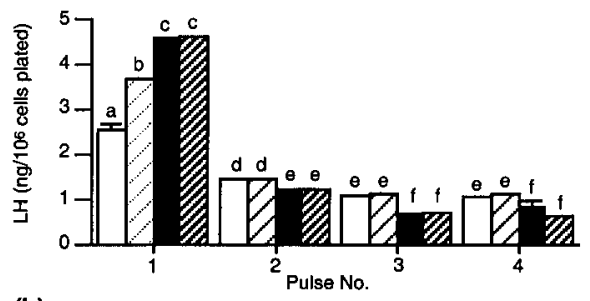

(b)
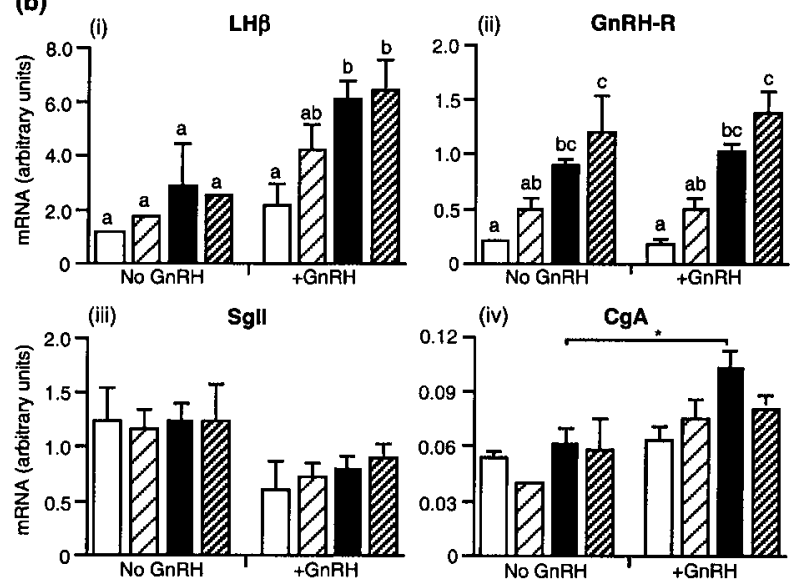

Figure 1 (a) LH secretion on treatment day 3 from L $\beta T 2$ cells cultured either in the absence of steroids or in the presence of $0 \cdot 2 \mathrm{nM} \mathrm{E2}, 20 \mathrm{nM}$ Dex or 0.2 nM E2 + $20 \mathrm{nM}$ Dex and given 4 pulses of $10 \mathrm{nM}$ GnRH per day for 3 days. Results for each pulse represent the total $\mathrm{LH}$ secreted during the $15 \mathrm{~min} \mathrm{GnRH}$ exposure and the $75 \mathrm{~min}$ inter-pulse interval. (b) mRNA levels for (i) $\mathrm{LH} \beta$, (ii) GnRH-R, (iii) Sgll and (iv) $\mathrm{CgA}$ in L $\beta \mathrm{T} 2$ cells cultured as described above, with and without GnRH. Different letters represent significant differences between treatment groups. The asterisk denotes the significant effect of GnRH within the Dex-treated group $\left({ }^{*} P<0 \cdot 05\right)$. Values represent means \pm S.E.M., $n=3$.

response to $\mathrm{GnRH}$ in the presence of E2+Dex, all subsequent experiments were conducted using this combination of steroids in the basal medium. A further preliminary experiment was carried out to investigate the effects of GnRH concentration on the regulation of $\mathrm{LH}$ secretion in L $\beta$ T2 cells. Cultures were pulsed with $\mathrm{GnRH}$ as before, but this time using concentrations of $0,10,50$ and $200 \mathrm{nM}$. LH secretion demonstrated a similar pattern to that shown in Fig. 1a, with less $(P<0 \cdot 001)$ LH secreted in pulses 2-4 compared with pulse 1 (data not shown). Figure 2a shows the LH secretory response for the first pulse only on each day of treatment. $\mathrm{LH}$ secretion increased $(P<0 \cdot 001)$ after $\mathrm{GnRH}$ treatment at all concentrations. On day $1 \mathrm{LH}$ secretion was similar in all $\mathrm{GnRH}$ treatment groups. On days 2 and $3 \mathrm{LH}$ secretion was reduced $(P<0 \cdot 001)$ in 50 and $200 \mathrm{nM}$ GnRH-treated cells, compared with $10 \mathrm{nM}$ GnRH-treated cells. On day 3 decreased $(P<0 \cdot 001)$ LH secretion was observed in $200 \mathrm{nM}$ GnRH-treated cells compared with $50 \mathrm{nM}$ (a)
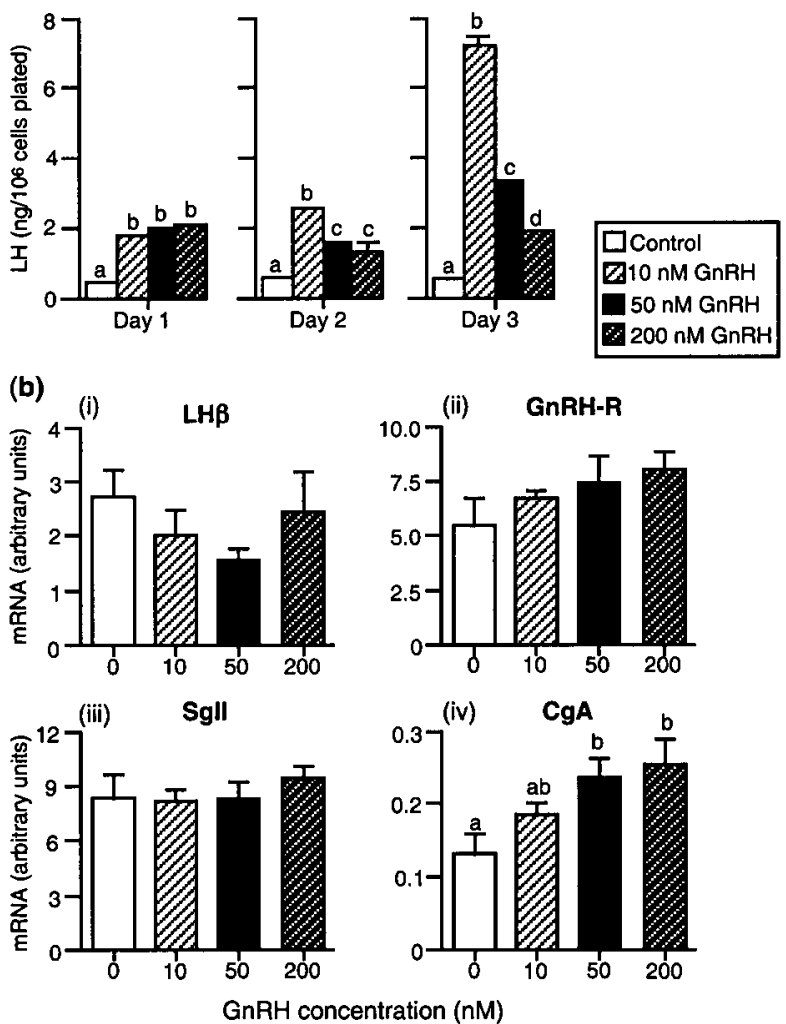

Figure 2 (a) LH secretion, in response to the first pulse of $\mathrm{GnRH}$ each day, from L $\beta T 2$ cells cultured in the presence of E2+Dex and given $0,10,50$ or $200 \mathrm{nM} \mathrm{GnRH}$ at 4 pulses/day for 3 days. Results for each pulse represent the total LH secreted during the 15 min GnRH exposure and the 75 min inter-pulse interval. (b) mRNA levels for (i) $\mathrm{LH} \beta$, (ii) GnRH-R, (iii) Sgll and (iv) $\mathrm{CgA}$ in $L \beta T 2$ cells cultured as described above. Different letters represent significant differences between treatment groups. Values represent means \pm S.E.M., $n=3$.

GnRH-treated cells. In this experiment, LH $\beta$, GnRH-R and SgII mRNA levels were unaffected by $\mathrm{GnRH}$ at any concentration (Fig. 2b (i-iii)). CgA mRNA levels, however, demonstrated concentration-dependent increases in response to $\mathrm{GnRH}$ treatment, significant $(P<0 \cdot 05)$ compared with controls at 50 and $200 \mathrm{nM}$ (Fig. $2 \mathrm{~b}$ (iv)). As stimulation of $\mathrm{LH}$ secretion was greatest when $\mathrm{GnRH}$ was applied at $10 \mathrm{nM}$ it was decided to continue to use this concentration in subsequent experiments.

\section{Experiment 3: effects of $\mathrm{GnRH}$ pulse frequency}

The previous experiments in this study utilised a $\mathrm{GnRH}$ pulse protocol of four $15 \mathrm{~min}$ pulses per day with $75 \mathrm{~min}$ inter-pulse intervals, but it is possible that alternative frequencies of $\mathrm{GnRH}$ exposure may have different effects on the stimulation of $\mathrm{LH}$ production, storage and secretion in L $\beta \mathrm{T} 2$ cells, which may in turn be reflected in changes 


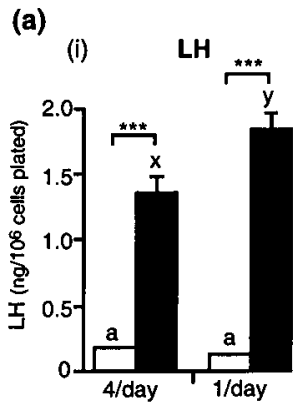

(b)

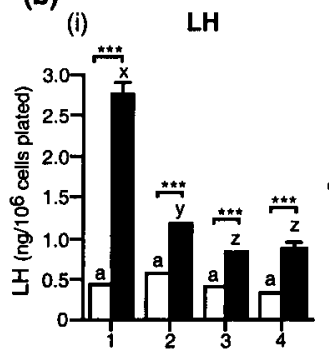

(ii)

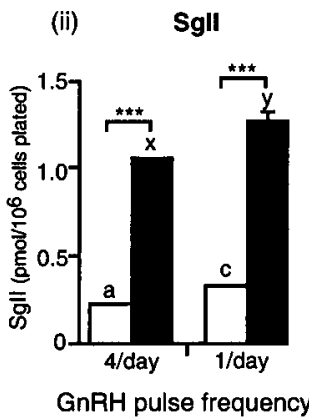

(ii)

Sgll

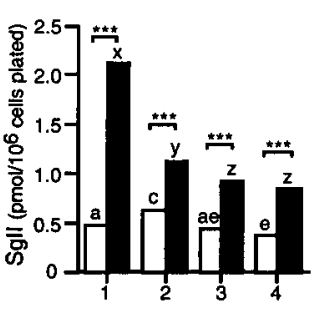

(iii) CgA324-337

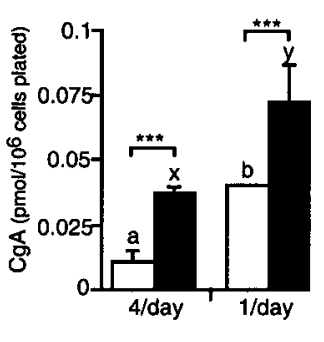

$\square$ Control $\square+\mathrm{GnRH}$

Figure 3 (a) (i) LH, (ii) Sgll and (iii) CgA324-337 secretion during the first 15 min pulse on day 3 from $\mathrm{L} \beta \mathrm{T} 2$ cells cultured in the presence of $\mathrm{E} 2+$ Dex and given 0 or $10 \mathrm{nM} \mathrm{GnRH}$ as either 4 pulses/day or as 1 pulse/day for 3 days. (b) (i) LH, (ii) Sgll, (iii) CgA324-337 and (iv) CgA17-38 secretion during the 4 pulses on day 3 from cells cultured in the presence of E2+Dex and given 0 or $10 \mathrm{nM} \mathrm{GnRH}$ as 4 pulses/day for 3 days. Different letters represent significant differences within treatment groups. Asterisks represent significant differences between treatment groups $\left({ }^{\star} P<0 \cdot 05,{ }^{* *} P<0 \cdot 01,{ }^{* * *} P<0 \cdot 001\right)$. Values represent means \pm S.E.M., $n=6$.

in the expression and secretion of the granins. This experiment looked in detail at the effects of giving only one $15 \mathrm{~min}$ pulse of $10 \mathrm{nM} \mathrm{GnRH}$ per day, compared with 4 pulses per day.

LH secretion during GnRH pulses over the 3 days of treatment for the 4 pulses/day group showed a similar pattern to that obtained in the first experiment, with more $(P<0 \cdot 001)$ LH secreted during pulse 1 compared with subsequent pulses (data not shown). Figure 3 a shows secretory responses of $\mathrm{LH}, \mathrm{SgII}$ and $\mathrm{CgA}$ on treatment day 3 during the first $15 \mathrm{~min}$ pulse of $\mathrm{GnRH}$ in the 4 pulses/day group and during the single $15 \mathrm{~min}$ pulse for the 1 pulse/day cells. LH, SgII and CgA secretion were increased $(P<0 \cdot 001)$ compared with controls after both GnRH treatments. There was a greater $(P<0 \cdot 001) \mathrm{GnRH}$ pulse response for all three proteins by the 1 pulse/day group compared with the 4 pulses/day group. However, whereas there was no difference in LH secretion from control cells in the two treatment groups, both SgII and CgA secretion were higher $(P<0 \cdot 05, P<0 \cdot 001$ respectively) in 1 pulse/day controls compared with 4 pulses/day controls (Fig. 3a (i-iii)).

The secretion of LH, SgII and CgA during all 4 pulses (15 min pulse and following $75 \mathrm{~min}$ inter-pulse interval) on day 3 for the 4 pulses/day group is shown in Fig. $3 b$. LH and SgII appeared to be released in a very similar fashion, with higher $(P<0 \cdot 001)$ levels of both released in response to $\mathrm{GnRH}$ in all pulses, and more $(P<0 \cdot 001) \mathrm{LH}$ and SgII released during pulse 1 compared with pulses $2-4$ (Fig. 3b (i, ii)). CgA secretion was measured by two assays, each detecting different regions of the protein. CgA324337 secretion was stimulated $(P=0 \cdot 001)$ by $\mathrm{GnRH}$ during the first pulse on day 3 , but was inhibited $(P<0 \cdot 05)$ by $\mathrm{GnRH}$ during the second pulse and there were no significant GnRH-induced changes during pulses 3 and 4 (Fig. 3b (iii)). CgA17-38 secretion was similar in control and GnRH-treated cells and during all pulses (Fig. 3b (iv)).

Total daily secretion of LH, SgII and CgA over the three treatment days was measured in cells given 1 pulse/day of GnRH. This represented the total $\mathrm{LH}$ secreted during the $30 \mathrm{~min}$ baseline incubation, the $15 \mathrm{~min}$ pulse and the overnight incubation. Total $\mathrm{LH}$ secretion increased $(P<0 \cdot 001)$ each day in response to $\mathrm{GnRH}$, and each day there was an increase $(P<0 \cdot 001)$ in LH secretion compared with the previous day, which could be attributed to an increase in cell number, since LH secretion from control cells on day 3 was also increased 


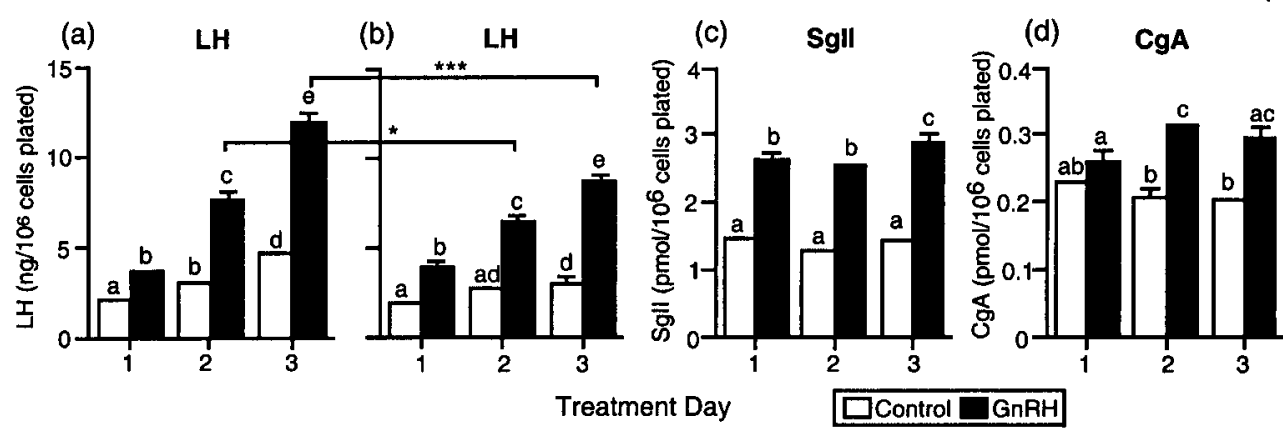

Figure 4 Total daily secretion from L $\beta T 2$ cells cultured in the presence of E2+Dex and given 0 or $10 \mathrm{nM}$ $\mathrm{GnRH}$ as either 4 pulses/day or 1 pulse/day for 3 days. (a) Total LH secretion from cells given 4 pulses/day. (b) Total LH, (c) total Sgll and (d) total CgA secretion from cells given 1 pulse/day. Different letters represent significant differences between control and treatment groups and between days. Values represent means \pm S.E.M., $n=6$.

$(P<0 \cdot 05)$ compared with day 1 (Fig. 4b). SgII secretion also increased $(P<0 \cdot 001)$ each day in response to GnRH. There was no difference in SgII secretion between days 1 and 2 , but day 3 secretion was slightly increased $(P<0 \cdot 05$, $P<0 \cdot 01$ respectively) compared with days 1 and 2 (Fig. $4 c)$. SgII secretion from control cells did not change over the treatment period. CgA secretion was increased $(P<0.001)$ compared with controls on days 2 and 3 only. There was no change in control secretion of this protein over the 3 days of treatment (Fig. 4d). Total LH secreted during the two pulse protocols was also compared. LH secretion from cells given 1 pulse/day of GnRH was less on days 2 and $3(P<0 \cdot 05, P<0 \cdot 01$ respectively) than from cells given 4 pulses/day (Fig. $4 \mathrm{a}$ and $\mathrm{b}$ ).

Intracellular levels of $\mathrm{LH}$ were unchanged by $\mathrm{GnRH}$ (Fig. 5a (i)), while SgII levels decreased after both GnRH treatments (4/day: $P<0 \cdot 01$; $1 /$ day: $P<0 \cdot 05$; Fig. 5a (ii)). Conversely, intracellular levels of $\mathrm{CgA}$ increased $(P<0 \cdot 05)$ after $\mathrm{GnRH}$ treatment in the 4 pulses/day group only.

In this experiment, LH $\beta$ mRNA levels increased significantly in response to both $\mathrm{GnRH}$ treatment protocols (4/day: $P<0 \cdot 01 ; 1 /$ day: $P<0 \cdot 001$; Fig. 5 b (i)). As found previously, GnRH-R (not shown) and SgII mRNA levels did not change in response to GnRH (Fig. 5b (ii)). CgA mRNA expression increased $(P<0 \cdot 05)$ in response to GnRH at 1 pulse/day only (Fig. $5 b$ (iii)).

\section{Discussion}

Specialised secretory granules, and their associated granin proteins, commonly found in neuroendocrine cells, are thought to be important mediators of the regulated secretory pathway (Ozawa \& Takata 1995). However, the regulation of granin synthesis and secretion in relation to $\mathrm{LH}$ and FSH production, and the role of different types of granules in the fundamental processes of normal reproduction, are still largely unclear. The present study used the L $\beta T 2$ pituitary gonadotroph cell model to examine the regulation of the major granin proteins $\mathrm{SgII}$ and $\mathrm{CgA}$, under conditions designed to stimulate secretion of $\mathrm{LH}$. Ultrastructural examination of L $\beta$ T2 cells has demonstrated the presence of secretory granules within the cytoplasm (Turgeon et al. 1996) and it has been confirmed that these cells are immunoreactive for both SgII and CgA (L Nicol, unpublished observation). $\mathrm{CgB}$, the third major granin protein reported to be present in gonadotrophs (Rundle et al. 1986, Watanabe et al. 1991), is virtually undetectable in L $\beta \mathrm{T} 2$ cells by immunocytochemistry (L Nicol, unpublished observation) and by RIA (M Stridsberg, unpublished observation), which may indicate that this granin plays little part in the storage and secretion of the gonadotrophins in these cells.

LH secretion in L $\beta \mathrm{T} 2$ cells was stimulated by the presence of steroids, an effect which appeared to be mediated, at least partly, by up-regulation of both GnRH-R and LH $\beta$ mRNAs. In contrast to a previous study (Turgeon et al. 1996), we did not observe any changes in steady state GnRH-R mRNA levels after GnRH treatment, only after steroid treatment, and we observed increased LH $\beta$ mRNA levels, not only as a result of GnRH treatment, but also due to the presence of Dex and E2+Dex in the culture medium. The stimulatory effects of Dex on LH synthesis and secretion, and GnRH-R mRNA levels, in L $\beta T 2$ cells are contrasted by the effects of glucocorticoids in normal pituitary cells. Dex blocked ovulation in cycling rats by inhibiting the normal preovulatory LH surge (Baldwin \& Sawyer 1974), and substantially decreased GnRH-stimulated LH secretion in cultured bovine anterior pituitary cells (Padmanabhan et al. 1983). In addition, corticosterone inhibited $\mathrm{LH}$ release from male (Tibolt \& Childs 1985) and female 
(a)
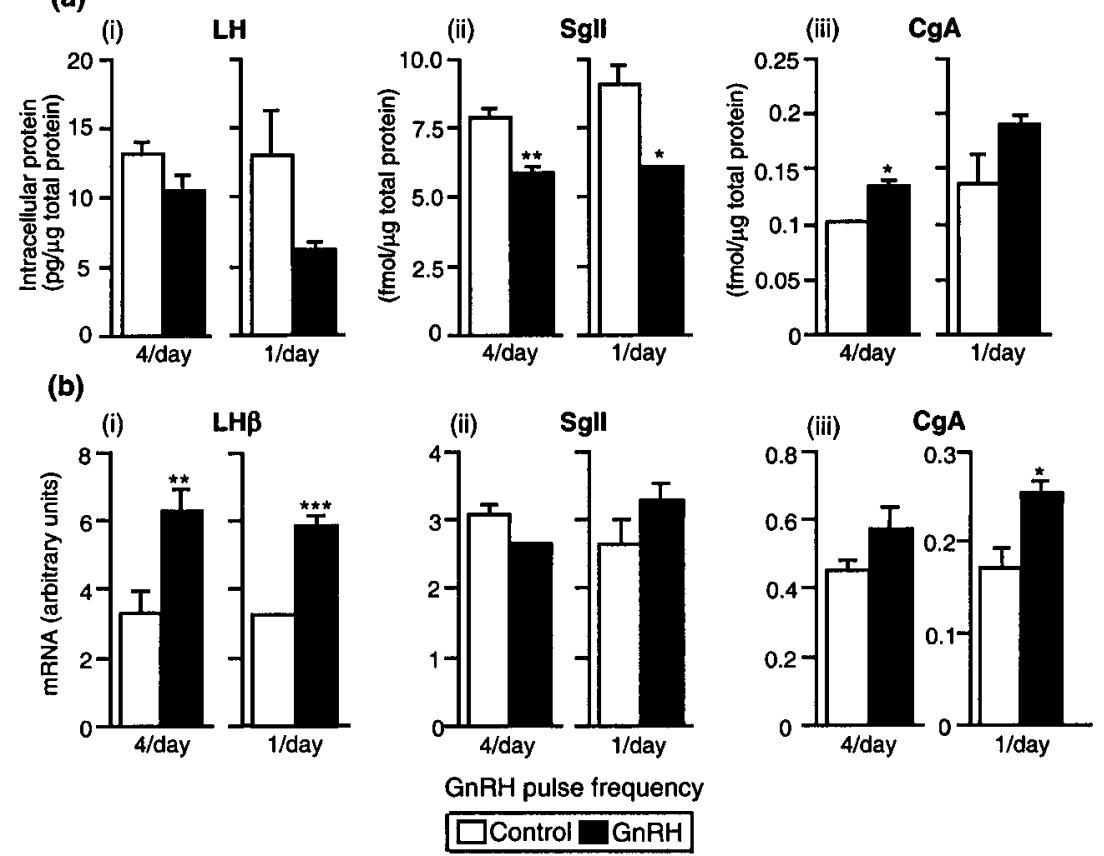

Figure 5 (a) Intracellular protein content for (i) LH, (ii) Sgll and (iii) CgA in L $\beta T 2$ cells cultured in the presence of E2 + Dex and given 0 or $10 \mathrm{nM} \mathrm{GnRH}$ as either 4 pulses/day or 1 pulse/day for 3 days. Values represent means \pm S.E.M., $n=3$. (b) mRNA levels for (i) LH $\beta$, (ii) Sgll and (iii) $\mathrm{CgA}$ in cells treated as described above. Asterisks denote significant differences between treatment groups. Values represent means \pm S.E.M., $n=6$.

(Baldwin et al. 1991) cultured rat anterior pituitary cells. Other studies have reported that $\mathrm{LH}$ release is unaffected by glucocorticoid treatment (Suter \& Schwartz 1985a,b). Pituitary GnRH-R levels were also unchanged by glucocorticoid treatment (Ringstrom et al. 1992). While normal gonadotrophs are terminally differentiated, L $\beta \mathrm{T} 2$ cells are potentially capable of further differentiation and it is possible that genetic differences exist between the two cell types which could explain the different glucocorticoid responses. Dex also has a detrimental effect on L $\beta$ T2 cell proliferation (Turgeon et al. 1996), but any direct relationship between frequency of cell division and the level of GnRH-mediated LH release has not yet been demonstrated.

There was no evidence for any steroid-induced changes in granin expression in these cells. The presence of Dex did, however, appear to enhance the up-regulation of $\mathrm{CgA}$ mRNA by GnRH. We did not investigate steroid concentration effects and it is possible that the concentrations used, or the duration of exposure, chosen as being effective in altering the expression of $\mathrm{LH} \beta$ and GnRH-R mRNA, and stimulating LH secretion, as reported previously (Turgeon et al. 1996), were not sufficient to elicit effects on the expression of SgII or CgA. It has been shown that pituitary expression of the granins is affected by steroid hormones and by corticosteroids. For example, in female rat pituitaries, ovariectomy increased SgII and $\mathrm{CgA}$ mRNA and protein levels, as well as increasing LH $\beta$, FSH $\beta$ and gonadotrophin $\alpha$-subunit mRNA levels and LH content (Anouar et al. 1991). Subsequent oestrogen replacement resulted in $\mathrm{CgA}$ message reverting to control levels with a very similar response to that of LH $\beta$. Oestrogen also down-regulated SgII mRNA levels, but in this case a higher concentration of E2 was required to produce an effect. Pituitary CgA content was decreased after E2 treatment, but there was no effect on the post-ovariectomy rise in SgII protein levels (Anouar et al. 1991). Similar results have been observed in vitro, where E2 was shown to down-regulate steady state mRNA levels for both $\mathrm{SgII}$ and $\mathrm{CgA}$ in cultured pituitary cell aggregates, but reduced intracellular content of CgA only (Anouar \& Duval 1992). Regulation of CgA expression by Dex has also been reported. CgA biosynthesis in rat pituitaries was stimulated by Dex treatment (Fischer-Colbrie et al. 1989) and it seems likely that this effect may be directly attributed to alterations in $\mathrm{CgA}$ gene transcription, as glucocorticoid response element-like sequences have been located on the CgA promoter (Iacangelo et al. 1991).

Exposure to GnRH resulted in up-regulation of the $\mathrm{LH}$ secretory response in L $\beta \mathrm{T} 2$ cells. This response was attenuated with increasing concentration of $\mathrm{GnRH}$, to the point where the LH secreted on day 3 of treatment with 
$10 \mathrm{nM}$ GnRH was nearly four times that secreted in response to $200 \mathrm{nM} \mathrm{GnRH}$. This result may be due to increased desensitisation of GnRH-R at the higher concentrations of GnRH used, with concomitant loss of intracellular signalling events leading to the release of LH (Weiss et al. 1995), rather than to any decrease in GnRH-R numbers, as there were no changes in GnRH-R mRNA levels at any of the concentrations of GnRH used. In the experiment to examine the effects of $\mathrm{GnRH}$ concentration we did not detect any changes in LH $\beta$ mRNA levels at any of the concentrations used. This was an unexpected result in the light of findings from the other experiments in this study, and of previously reported up-regulation of LH $\beta$ mRNA after GnRH exposure (Turgeon et al. 1996). One explanation for this could be that GnRH may not have been adequately removed from the cells after the $15 \mathrm{~min} \mathrm{GnRH}$ pulses, essentially leading to low levels of constant GnRH exposure during the 75 min inter-pulse intervals and the overnight incubations, resulting in decreased responsiveness of the intracellular pathways involved in GnRH-mediated signalling and subsequent down-regulation of LH $\beta$ mRNA synthesis.

Stimulation of the cells with increasing concentrations of GnRH appeared to have no effect on the expression of SgII, but a concentration-dependent increase in CgA mRNA levels was observed. CgA mRNA levels were also increased in cells given the lower concentration $(10 \mathrm{nM})$ of $\mathrm{GnRH}$ at a reduced pulse frequency, and these cells released less LH on a daily basis than cells given GnRH at the higher frequency. Intracellular levels of $\mathrm{CgA}$ also increased after exposure to $10 \mathrm{nM} \mathrm{GnRH}$, but, in contrast to the mRNA results, this was significant only with the higher frequency of GnRH treatment.

Although there were no changes to SgII mRNA expression, intracellular levels of SgII were decreased after GnRH treatment. This presumably reflected the GnRHinduced stimulation of SgII secretion which was observed at both pulse frequencies. Although intracellular storage of LH was not changed significantly by $\mathrm{GnRH}$ treatment in this study, there was a trend towards a decrease, in line with that of SgII. The pattern of SgII secretion in cells given multiple pulses of $\mathrm{GnRH}$ was very similar to that of $\mathrm{LH}$, and indicates probable co-secretion of the two proteins. The co-secretion of $\mathrm{LH}$ and SgII has been reported previously in perifused pituitary cell aggregates (Sion et al. 1988) and the two proteins are commonly found within the same granules in rat (Watanabe et al. 1991), sheep (Crawford et al. 2002a) and mouse (Crawford et al. 2002b) gonadotrophs. Although CgA secretion in $\mathrm{L} \beta \mathrm{T} 2$ cells was also stimulated by $\mathrm{GnRH}$ treatment to a certain extent, release during the 4 pulses/day experiment did not show such a well-defined pattern as those of $\mathrm{LH}$ and SgII, with GnRH-induced stimulation of secretion only evident for pulse 1. Interestingly, the daily total secretion of SgII from cells given only 1 pulse/day of GnRH did not correlate with that of LH. SgII secretion increased each day in response to $\mathrm{GnRH}$, as did that of $\mathrm{CgA}$, but whereas $\mathrm{LH}$ secretion from both control and GnRH-stimulated cells increased daily, probably as a result of cell proliferation, neither SgII nor CgA showed cell density-dependent increases in daily secretion. These results suggest that increasing cell density may have a detrimental effect on the basal secretion of both SgII and CgA.

It appears, therefore, that in $\mathrm{L} \beta \mathrm{T} 2$ cells, there is a close correlation between $\mathrm{LH}$ and SgII storage and secretion and an inverse correlation between $\mathrm{CgA}$ production and $\mathrm{LH}$ secretion. It has been reported that higher levels of pituitary $\mathrm{CgA}$ coincide with greater numbers of large sized secretory granules, typically immunopositive for $\mathrm{CgA}$, in gonadotrophs (Watanabe et al. 1998). As these granules are typically also immunopositive for $\mathrm{LH}$, it is possible that more $\mathrm{LH}$ is being diverted, with or without SgII, into storage in these larger granules, rather than into the small LH/SgII immunopositive granules, which are released in response to $\mathrm{GnRH}$ stimulation. Further studies are required to determine the composition and distribution of granules within $\mathrm{GnRH}$-stimulated L $\beta \mathrm{T} 2$ cells.

As well as being an integral component of secretory granules, the granins are known to function as precursors of biologically active peptides (Huttner et al. 1991). For $\mathrm{CgA}$, the extent to which processing occurs appears to be highly tissue-dependent, with a correlation between the level of the prohormone convertase PC2 and the levels of processed forms of this protein (Arden et al. 1994). In the present study CgA levels have been quantified using two assays. The first used an antibody against amino acids hCgA324-337 which detects the WE-14 region of CgA (Portela-Gomes \& Stridsberg 2001). It is not clear whether this assay detects mainly intact $\mathrm{CgA}$, or also $\mathrm{CgA}$-derived fragments, but it is thought that processing within this region is less common than in the terminal regions. The second assay utilised an antibody against amino acids hCgA17-38 which detects the CgA-derived peptide vasostatin. It has been shown previously that this assay is largely specific for vasostatin and generally does not detect the intact CgA molecule (Stridsberg et al. 2000). Processing does appear to occur in L $\beta$ T2 cells as the hCgA17-38 vasostatin assay detected reasonable levels of this peptide in the samples analysed. However, vasostatin did not appear to be regulated by GnRH, and samples collected over the duration of the 4 pulses on day 3 of GnRH treatment showed no differences in levels of secretion indicating that this peptide is probably constitutively released from L $\beta \mathrm{T} 2$ cells. The function of vasostatin in L $\beta \mathrm{T} 2$ cells is unknown, but it has previously been shown to have a suppressive effect on vascular contractility and on parathyroid hormone secretion (Angeletti et al. 1994, 1996).

In conclusion, the results reported in this study indicate that there is a close correlation between the GnRHstimulated release of $\mathrm{LH}$ and SgII from L $\beta \mathrm{T} 2$ cells, and 
suggest that SgII may have an important role to play in the regulated secretion of $\mathrm{LH}$, possibly by inducing the aggregation of LH to facilitate trafficking into specialised secretory granules. CgA secretion, on the other hand, does not appear to be closely associated with the release of $\mathrm{LH}$, but evidence that $\mathrm{CgA}$ synthesis and storage are regulated by $\mathrm{GnRH}$ may indicate that it is also involved in the control of regulated LH secretion, perhaps by influencing the amount of $\mathrm{LH}$ sorted into the different types of secretory granules and thus altering the amount of $\mathrm{LH}$ available for release in response to $\mathrm{GnRH}$ stimulation.

\section{Acknowledgements}

We thank Dr P Mellon for providing the L $\beta$ T2 cells and Dr A Parlow, NIDDK and the NHPP for providing reagents for the LH RIA. We also thank Dr R FischerColbrie for the bovine SgII cDNA clone, Mr R Sellar for the mouse GnRH-R cDNA clone and Dr K Turner for the rat $18 \mathrm{~S}$ rRNA cDNA clone.

\section{References}

Angeletti RH, Aardal S, Serck-Hanssen G, Gee P \& Helle KB 1994 Vasoinhibitory activity of synthetic peptides from the amino terminus of chromogranin A. Acta Physiologica Scandinavica 152 $11-19$.

Angeletti RH, Mints L, Aber C \& Russell J 1996 Determination of residues in chromogranin A-16-40 required for inhibition of parathyroid hormone secretion. Endocrinology 137 2918-2922.

Anouar Y \& Duval J 1991 Differential expression of secretogranin II and chromogranin A genes in the female rat pituitary through sexual maturation and estrous cycle. Endocrinology 128 1374-1380.

Anouar Y \& Duval J 1992 Direct estradiol down-regulation of secretogranin II and chromogranin A mRNA levels in rat pituitary cells. Molecular and Cellular Endocrinology 88 97-104.

Anouar Y, Benie T, de Monti M, Counis R \& Duval J 1991 Estradiol negatively regulates secretogranin II and chromogranin A messenger ribonucleic acid levels in the female rat pituitary but not in the adrenal. Endocrinology 129 2393-2399.

Arden SD, Rutherford NG, Guest PC, Curry WJ, Bailyes EM, Johnston CF \& Hutton JC 1994 The post-translational processing of chromogranin A in the pancreatic islet: involvement of the eukaryote subtilisin PC2. Biochemical Journal 298 521-528.

Baldwin DM \& Sawyer CH 1974 Effects of dexamethasone on LH release and ovulation in the cyclic rat. Endocrinology 94 1397-1403.

Baldwin DM, Srivastava PR \& Krummen LA 1991 Differential actions of corticosterone on luteinizing hormone and follicle-stimulating hormone biosynthesis and release in cultured rat anterior pituitary cells: interactions with estradiol. Biology of Reproduction 44 1040-1050.

Burgess TL \& Kelly R 1987 Constitutive and regulated secretion of proteins. Annual Review of Cell Biology 3 243-293.

Chanat E \& Huttner WB 1991 Milieu-induced, selective aggregation of regulated secretory proteins in the trans-Golgi network. Journal of Cell Biology 115 1505-1519.

Childs GV, Unabia G, Tibolt R \& Lloyd JM 1987 Cytological factors that support nonparallel secretion of luteinizing hormone and follicle-stimulating hormone during the estrous cycle. Endocrinology 121 1801-1813.
Childs GV, Unabia G \& Rougeau D 1994 Cells that express luteinizing hormone ( $\mathrm{LH}$ ) and follicle-stimulating hormone (FSH) $\beta$-subunit messenger ribonucleic acids during the estrous cycle: the major contributors contain LH $\beta$, FSH $\beta$, and/or growth hormone. Endocrinology 134 990-997.

Clarke IJ \& Cummins JT 1982 The temporal relationship between gonadotrophin releasing hormone $(\mathrm{GnRH})$ and luteinizing hormone $(\mathrm{LH})$ secretion in ovariectomized ewes. Endocrinology 111 $1737-1739$.

Crawford JL \& McNeilly AS 2002a Co-localisation of gonadotrophins and granins in gonadotrophs at different stages of the oestrous cycle in sheep. Journal of Endocrinology 174 179-194.

Crawford JL, McNeilly JR, Nicol L \& McNeilly AS $2002 b$ Enhancement of secretogranin II (SgII) storage in GnRH-deprived male mice promotes co-aggregation with LH $\beta$ and intracellular granule storage in gonadotropes. Reproduction (In Press).

Currie RJW \& McNeilly AS 1995 Mobilisation of LH secretory granules in gonadotrophs in relation to gene expression, synthesis and secretion of LH during the preovulatory phase of the sheep oestrous cycle. Journal of Endocrinology 147 259-270.

Farnworth PG 1995 Gonadotrophin secretion revisited. How many ways can FSH leave a gonadotroph? Journal of Endocrinology 145 387-395.

Fischer-Colbrie R, Wohlfahrter T, Schmid KW, Grino M \& Winkler H 1989 Dexamethasone induces an increased biosynthesis of chromogranin A in rat pituitary gland. Journal of Endocrinology 121 487-494.

Gharib SD, Wierman ME, Shupnik MA \& Chin WW 1990 Molecular biology of the pituitary gonadotrophins. Endocrine Reviews 11 177-199.

Huttner WB, Gerdes H-H \& Rosa P 1991 The granin (chromogranin/secretogranin) family. Trends in Biochemical Sciences 16 27-30.

Iacangelo AL, Grimes M \& Eiden LE 1991 The bovine chromogranin A gene: structural basis for hormone regulation and generation of biologically active peptides. Molecular Endocrinology 5 1651-1660.

Liu YC, Kato Y, Inoue K, Tanaka S \& Kurosumi K 1988 Co-localization of LH $\beta$ and FSH $\beta$ mRNAs in the porcine anterior pituitary by in situ hybridization with biotinylated probes. Biochemical and Biophysical Research Communications 154 80-90.

Lloyd JM \& Childs GV 1988 Differential storage and release of luteinizing hormone and follicle-releasing hormone from individual gonadotropes separated by centrifugal elutriation. Endocrinology 122 1282-1290.

McNeilly JR, Brown P, Clark AJ \& McNeilly AS 1991 Gonadotrophin-releasing hormone modulation of gonadotrophins in the ewe: evidence for differential effects on gene expression and hormone secretion. Journal of Molecular Endocrinology 7 35-43.

McNeilly JR, Brown P, Mullins J, Clark AJ \& McNeilly AS 1996 Characterization of the ovine LH $\beta$-subunit gene: the promoter is regulated by $\mathrm{GnRH}$ and gonadal steroids in transgenic mice. Journal of Endocrinology 151 481-489.

Ozawa H \& Takata K 1995 The granin family - its role in sorting and secretory granule formation. Cell Structure and Function 20 415-420.

Padmanabhan V \& McNeilly AS 2001 Is there an FSH-releasing factor? Reproduction 121 21-30.

Padmanabhan V, Keech C \& Convey EM 1983 Cortisol inhibits and adrenocorticotropin has no effect on luteinizing hormone-releasing hormone-induced release of luteinizing hormone from bovine pituitary cells in vitro. Endocrinology 112 1782-1787.

Portela Gomes GM \& Stridsberg M 2001 Selective processing of chromogranin A in the different islet cells in human pancreas. Journal of Histochemistry and Cytochemistry 49 483-490.

Ringstrom SJ, Suter DE, Hostetler JP \& Schwartz NB 1992 Cortisol regulates secretion and pituitary content of the two gonadotropins differentially in female rats: effects of gonadotropin-releasing hormone antagonist. Endocrinology 130 3122-3128. 
Rundle S, Somogyi P, Fischer-Colbrie R, Hagn C, Winkler H \& Chubb IW 1986 Chromogranin A, B and C: immunohistochemical localization in ovine pituitary and the relationship with hormone-containing cells. Regulatory Peptides 16 217-233.

Sion B, Chanat E, Duval J \& Thieulant ML 1988 Peptides co-released with luteinizing hormone by perifused pituitary cell aggregates. Molecular and Cellular Endocrinology 60 151-161.

Stridsberg M, Oberg K, Li Q, Engstrom U \& Lundqvist G 1995 Measurements of chromogranin A, chromogranin B (secretogranin I), chromogranin C (secretogranin II) and pancreastatin in plasma and urine from patients with carcinoid tumours and endocrine pancreatic tumours. Journal of Endocrinology 144 49-59.

Stridsberg M, Angeletti RH \& Helle KB 2000 Characterisation of $\mathrm{N}$-terminal chromogranin A and chromogranin B in mammals by region-specific radioimmunoassays and chromatographic separation methods. Journal of Endocrinology 165 703-714.

Suter DE \& Schwartz NB 1985a Effects of glucocorticoids on responsiveness of luteinizing hormone and follicle-stimulating hormone to gonadotropin-releasing hormone by male rat pituitary cells in vitro. Endocrinology 117 855-859.

Suter DE \& Schwartz NB 1985 b Effects of glucocorticoids on secretion of luteinizing hormone and follicle-stimulating hormone by female rat pituitary cells in vitro. Endocrinology 117 849-854.

Taragnat C, Bernier A \& Fontaine J 1998 Gonadotrophin storage patterns in the ewe during the oestrus cycle or after long-term treatment with a GnRH agonist. Journal of Endocrinology 156 149-157.

Thomas SG \& Clarke IJ 1997 The positive feedback action of estrogen mobilizes LH-containing, but not FSH-containing secretory granules in ovine gonadotropes. Endocrinology 138 1347-1350.

Tibolt R \& Childs GV 1985 Cytochemical and cytophysiological studies of gonadotropin-releasing hormone $(\mathrm{GnRH})$ target cells in the male rat pituitary: differential effects of androgens and corticosterone on GnRH binding and gonadotropin release. Endocrinology 117 396-404.
Tougard C \& Tixier-Vidal A 1994 Lactotropes and gonadotropes. In The Physiology of Reproduction, pp 1711-1747. Eds E Knobil \& JD Neill. New York: Raven Press.

Tsutsumi M, Zhou W, Millar RP, Mellon PL, Roberts JL, Flanagan CA, Dong K, Gillo BC \& Sealfon SC 1992 Cloning and functional expression of a mouse gonadotropin-releasing hormone receptor. Molecular Endocrinology 6 1163-1169.

Turgeon JL, Kimura Y, Waring DW \& Mellon PL 1996 Steroid and pulsatile gonadotropin-releasing hormone $(\mathrm{GnRH})$ regulation of luteinizing hormone and $\mathrm{GnRH}$ receptor in a novel gonadotrope cell line. Molecular Endocrinology 10 439-450.

Vale W, Rivier C, Hsueh A, Campen C, Meunier H, Bicsak T, Vaughan J, Corrigan A, Bardin W, Sawchenko P, Petraglia F, Yu J, Plotsky P, Spiess J \& Rivier J 1988 Chemical and biological characterization of the inhibin family of protein hormones. Recent Progress in Hormone Research 44 1-37.

Watanabe T, Uchiyama Y \& Grube D 1991 Topology of chromogranin A and secretogranin II in the rat anterior pituitary: potential marker proteins for distinct secretory pathways in gonadotrophs. Histochemistry 96 285-293.

Watanabe T, Jeziorowski T, Wuttke W \& Grube D 1993 Secretory granules in hyperstimulated male rat gonadotropes. Journal of Histochemistry and Cytochemistry 41 1801-1812.

Watanabe T, Banno T, Jeziorowski T, Ohsawa Y, Waguri S, Grube D \& Uchiyama Y 1998 Effects of sex steroids on secretory granule formation in gonadotropes of castrated male rats with respect to granin expression. Endocrinology 139 2765-2773.

Weiss J, Cote CR, Jameson JL \& Crowley WF 1995 Homologous desensitization of gonadotropin-releasing hormone $(\mathrm{GnRH})$-stimulated luteinizing hormone secretion in vitro occurs within the duration of an endogenous GnRH pulse. Endocrinology $136138-143$.

Received 22 March 2002

Accepted 16 May 2002 